\title{
Psychoanalytic Reading of Love and Desire in Somerset
}

\section{Maugham's Of Human Bondage}

\author{
Amin Ettehadi ${ }^{1 *} \&$ Roohollah Reesi Sistani ${ }^{1}$ \\ ${ }^{1}$ Islamic Azad University, Kerman Branch, Iran \\ *Amin Ettehadi, E-mail: amin13671336@gmail.com
}

Received: January 1, 2017

Accepted: January 19, 2017 Online Published: February 3, 2017

doi:10.22158/selt.v5n1p58

URL: http://dx.doi.org/10.22158/selt.v5n1p58

\begin{abstract}
The present study was a comprehensive psychoanalysis of the idea of love and desire in Somerset Maugham's Of Human Bondage. The study explored the relationship Philip Carey, the main character, develops with Other people throughout the novel. To further enrich the analysis, Lacan's theory of human love and desire was employed to provide a psychoanalytic examination of Philip Carey's bond of love for Mildred, on the one hand, and his gradual loss of identity in his desire towards her, on the other. The study inspected the nature of Philip's desire for Mildred and shows how he turnd to a desiring subject in his bond to her and finally reached a state of selflessness and depended heavily on Mildred as the object of his desire which drove him towards self-contempt and a masochistic denial of real facts in his life.
\end{abstract}

\section{Keywords}

love, desire, Other, subjectivity, psychoanalysis

\section{Introduction}

Samuel Rogal argues in A Somerset Maugham Encyclopedia that "Maugham's fiction reflect his supreme ability to capture the more interesting aspects of human nature and his agnosticism rob the majority of his fictional characters of their individuality" (p. 97). Rogal believes that Maugham's realistic narrative owes a lot to his life and borrows many characters from real people in his surroundings. Of Human Bondage is an early twentieth century novel that has many features of a classic masterpiece in English literature. Fact and fiction are skillfully mingled in Of Human Bondage as Maugham mostly narrates the real story of his life in the persona of Philip Carey. We can easily recognize in Philip's narrative the experience of Maugham's own life. In other words, Philip is a projection of the author's real self in his rather hard life. Both the author and his main character suffer from death of both parents as a small boy; both spend unhappy years at the vicarage with a clergyman-uncle; they were both shy, sensitive boys at school who were teased by fellow students 
because of their physical problems (Maugham suffered from stuttering and Philip had a clubfoot); these are followed for both the author and Philip by a period of intellectual growth.

Maugham's Of Human Bondage is the story of Philip Carey's progress from illusion into reality, a sort of pilgrimage through which Philip realizes the true meaning of life and comes to an understanding of himself as well as others in his immediate surroundings. Maugham depicts a very simple yet layered picture of human relations in the novel and soon wins the confidence of his readers in creating Philip as an acceptable character. However, as Philip grows up, the author manifests obstacles on his journey towards maturity and casts him into a series of problematic relations with some women to show human follies in an irrational and dependent passion for another human being. Of Human Bondage is the tragic story of Philip's injuries for loving the detestable Mildred who never proves to deserve his genuine love.

The present study is a psychoanalytic reading of human subjectivity in Somerset Maugham's $O f$ Human Bondage. It deals with the nature of desire and love and how they determine social existence of Philip Carey as the main character of the novel. To comprehend and thereby fully appreciate Somerset Maugham's work, one requires some knowledge of the forces working together to form the basic function of the unconscious desire in Philip's relationship with Others, which are made clear in this research work. Thus, Lacan's theories on human subjectivity, love and desire are explained first to provide for a better understanding of the mechanism by which Philip loses his own identity in encountering Others.

\section{Conceptual Framework}

Modern psychoanalysis originated with the work of Sigmund Freudin early in twentieth century and showed to be highly influential in defining the root of some human behaviors which were formerly unknown to critics. However, the realm of psychoanalysis underwent fundamental transformations and covered many aspects of human psyche. Jacques Lacan (1901-1981) is unquestionably the most important contemporary psychoanalyst after Sigmund Freud, whose theories on human psyche has had great effects on psychoanalysis as well as literature. Lacan did not revolutionize the psychoanalytic practice but his ideas on the workings of the unconscious solved many problems related to the origin of human behavior and made him the most influential psychoanalyst in the second half of the twentieth century.

Lacan's critical theories were not limited only to psychoanalytic practice and contributed greatly to literature and psychoanalytic criticism of the subject and its relationship to Others and the role of unconscious desire in shaping human behavior. His systematic studies contributed to better understanding of literature and literary criticism. As Sean Homer argues in Routledge Introduction to Jacque Lacan, "Lacanian psychoanalysis contributed to literary criticism the crucial link of subjectivity to the unconscious and to language, as well as an understanding of sexual difference as constituted at an unconscious level" (p. 2). Thus, Lacan's theory of the unconscious as structured like language is 
adopted in literary criticism to analyze the relationship between the subject and the text. In fact, the focus of Lacanian criticism in literature is not upon the unconscious of the character or the author but upon the text itself and the relationship between text and reader.

\subsection{Subjectivity and Desire}

The question of the subject and what makes up one's individual identity is central to modern philosophy. Many philosophers in the twentieth century tried to find the true meaning behind the concept of the "self" as the source of one's emotions and reflections. In an introduction to Subjectivity: Theories of the Self From Freud to Haraway, Nick Mansfield defines subjectivity as "an abstract or general principle that defies our separation into distinct selves and that encourages us to imagine that, or simply helps us to understand why, our interior lives inevitably seem to involve other people, either as objects of need, desire and interest or as necessary sharers of common experience" (p. 3). Based on this definition, which is hold by many postmodern thinkers of our time, the subject is always defined in relation to a set of principles, objects or other subjects in a given community. In fact, one is always in relation to other subjects who give meaning to his existence. Therefore, the word subject implies that the self is not separated from others and one's identity is determined in interactions with Others.

The critical stage for the development of subjectivity in Lacanian theory is the mirror stage in the Imaginary Order. Lacan argues that prior to the mirror stage the child feels himself in complete union with his mother and does not consider himself as an entity separate from the body of his mother. There is nothing external to this relationship. In fact, the child feels himself as part of a unified system and fails to experience himself as an isolated being that works within this system and interacts with it. But in the mirror stage the child grasps a whole picture of himself as an isolated and separated being and develops a new sense of subjectivity. Lacan's theory of the development of the subject continues significantly in the Symbolic Order where the subject falls into the realm of language. This is maybe the most important aspect of his theory on human subjectivity where the Other enters into the relationship and determines one's sense of selfhood. By introducing the Other into the Symbolic Order, Lacan relates subjectivity to the discourse of the other, within which "the subject is implicated in and linked to other subjects, general truths and shared principles" (Mansfield, p. vi). It is in this interaction with Others that one's own sense of being is lost and the individual always suffers from this loss of identity. The subject is lost in his relationship to the Other. It is impossible to gain any sense of selfhood outside of relationship with the Other. Selfhood, in fact, can only come to us in this relationship.

In developing his idea of the Symbolic Order Lacan was influenced by the structural anthropologist Claude Lévi-Strauss and linguist Ferdinand de Saussure. Lacan developed his central notion of the symbolic order and the subject as subject of the signifier, indicating that one's subjectivity is a function of the system of signification where his being is defined in relation to others. This facilitated Lacan's break with traditional psychoanalysis and paved the way for his major idea that the unconscious is structured like language. Sean Homer describes in Jaques Lacan that "The unconscious is governed by 
the rules of the signifier as it is language that translates sensory images into structure. We can only know the unconscious through speech and language; therefore, similar kinds of relationships exist between unconscious elements, signifiers and other forms of language" (p. 69). This means that the unconscious works as the process of signification. It is something that signifies and must be deciphered. The subject for Lacan is a lacking subject who has no subtle and independent being and relies on Others to recognize him and shape his desires.

Lacan's main point in regard to desire is that language precedes our birth, affects us in childhood, and flows into our unconscious and shapes our desires and fantasies. Without language there would be no desire. Thus, one is subject to language. That is to say, the subject has to accept to express his desires and demands in words because language is the only medium through which Others can understand him. Moreover, when a subject is encountered with an Other, he submits to him and this is a necessary choice because one relies on the Other to be recognized as a subject. Bruce Fink argues in "The Subject and the Other's Desire" that "The cause of the subject's physical presence in the world was a desire for something (pleasure, revenge, fulfillment, power, eternal life, etc.) on the part of the child's parents. One or both of them wanted something, and the child results from that wanting" (p. 244). In Seminar VIII, Lacan himself gives a detailed definition of desire and how it determines a subjects' being: Man is marked, he is troubled by all that is called symptom. It is this that links him to his desires. The desire of the subject is essentially the desire of the Other. This genetive is at once subjective and objective. Desire in the place where the Other is, desire for being able to be at this place-and desire for some alterity. To satisfy a search for an objective to know what this other who comes to find us desires we lend it there, to the function of the subjective to represent not at all the object the desire targets, but the signifier. It is necessary to know how to fill its place, in as much as the subject must be able to locate there the lacking signifier (p. 314).

This desire which arises from the lack of the Other is mostly problematic. The subject who depends on another for recognition and satisfaction of his own desire turns to be in constant need of the presence of the Other. In fact, the person turns to a desiring subject and his desire becomes the desire of the Other. Lacan shows this notion in relationship between the child (as the subject) and the mother (as the Other) where the child illusively considers himself to be in the position of the desire of his mother. Nevertheless, the child comes to realize that his mother's object of desire is his father not him. This is the paternal metaphor and becomes the signifier of the mother's desire. This is a very dangerous situation for the child since he finds out that he plays no role in satisfying the desire of his mother. In Seminar XVII, Lacan writes: “The mother's role is her desire. That is of capital importance. Her desire is not something you can bear easily, as if it were a matter of indifference to you. It always leads to problems. The mother is a big crocodile and you find yourself in her mouth. You never know what may set her off suddenly, making those jaws clamp down. That is the mother's desire" (p. 129).

Slavoj Zizek argues inThe Sublime Object of Ideology that the meaninglessness of desire and its unattainability is the problem of the fulfillment of desire. Zizek states that when someone finds an 
object which has all the properties that he desires, he still feels disappointed because he thinks it is not what he desires and desires for something else. The nature of desire is that one asks for something but when he gets closer to attaining it he feels it is not exactly what he wanted and so he shifts to something new in the hope of satisfying his desire, which seems to always escape him (Zizek, pp. 341-345). Similarly, in Why Do Women Write More Letters than They Post Darian Leader finds Lacanian desire the process of signification and the act of moving from one signifier to another and defines it "as the difference between the original message and that which arrives at the end. The key here is that desire is not the message itself. It is neither the original sentence nor the final one, but the process or structure of distortion itself" (p. 110).

This means that desire constantly moves from one signifier to another because "one signifier constantly refers to another in a perpetual deferral of meaning. Desire is also characterized by exactly the same never-ending process of continual deferral. since desire is always desire for something else, as soon as the object of desire is attained, it is no longer desirable, and the subject's desire fixes on another object" (Evans, p. 117). That is to say, desire for Lacan is always a desire for something else as if it is never going to settle fixed on some point. Maybe desire has no specific character or attribute and to desire or not desire make no difference. In Seminar XI Lacan does not distinguish between the two: "But what does not wanting to desire mean? The whole of analytic experience - which merely gives form to what is for each individual at the very root of his experience - shows us that not to want to desire and to desire are the same thing. To desire involves a defensive phase that makes it identical with not wanting to desire. Not wanting to desire is wanting not to desire" (p. 235).

\subsection{Love}

Love for Lacan is a deceptive and wrongful emotion. He states that love is the result of the wrong identification of the subject with his object of desire and cannot be treated as true feelings because the subject does not love his object of desire but an image that creates of this object. In simple words, when a man (the subject) says he passionately loves a woman (his object of desire), he in fact loves the image he has created of the woman, not the woman as she is. This love affair for Lacan is not a progressive act of union that satisfies needs of the lovers. It is not a positive feeling of a person towards another. On the contrary, it has destructive effects on the subject and leads to his constant sufferings because one cannot satisfy his desire. Thus, love is more a relationship of lack of something in the other not what she has. Lacan says that when one loves an Other, he gives nothing of himself and finally comes to accept the emptiness in the Other. Similarly, In I Can't Love You, Salecl interprets Lacan's ides:

The enchantment of love is how the subject deals, on the one hand with, with his or her own lack, and, on the other hand, with the lack $n$ the loved one. What love as a demand targets in the other is therefore the object in him or herself, the Real, the non-symbolizable kernel around which the subject organizes his or her desire. What gives to the beloved his or her dignity, what leads the loving subject to the survalorization of the beloved, is the presence of the object in him or her (p. 18).

In order to formulate his theory of love, Lacan utilizes the tradition of courtly love where a single 
knight falls in love with a married lady and desires not her body but her presence. He subjects himself to the desire of the lady and may take adventurous journeys to please her. This was an elevated concept of love developed in Middle Ages. What Lacan draws from courtly love is the impossibility of unity between the aristocratic lovers to fulfill their desires, because there is always an obstacle between them. The lady is married to another man and his object of desire is directed to another lover. Thus, the knight has no chance of winning the lady. In Lacan's words, "The object involved, the feminine object, is introduced oddly enough through the door of privation or of inaccessibility. Whatever the social position of him who functions in the role, the inaccessibility of the object is posited as a point of departure" (p. 149).

By the example of courtly love and the relationship between the knight and the lady, Lacan points out to idealized image of the lady in the mind of the knight whom he can never reach in reality. The lady is the symbol of the Other who is the object cause of his desire but can never be attained. In fact, this is a relationship of giving nothing and receiving nothing in return from the Other. Interestingly, both sides accept this emptiness in their relationship. In the process of loving the Other, the subject loses his own sense of being and relies on the Other for his existence because he feels he is dependent for his existence on the Other and desires her presence continuously. In Seminar $X X$ we have, "If love is what is happening in that object toward whom, led by our desire, we are extending our hand and who, at the moment when our desire bursts into fire, for a moment offers a response in the form of that other hand that extends towards us as its desire" (Lacan, p. 212).

When one falls in love with an Other, he projects his lack and being in need of her and expects her to desire him in return. The relationship between the subject and the Other becomes problematic when the Other fails to return the lover's love and does not fill his emptiness. In Seminar X, Lacan writes "What we give in love, is essentially what we do not have and, when what we do not have returns to us, there is undoubtedly a regression and at the same time a revelation of the way in which we have failed the person in representing his lack" (p. 95). There are elements in Lacan's work which emphasize on similarities between love and desire. Firstly, they are both similar in that neither can ever be satisfied. Secondly, the structure of love as the wish to be loved is identical to the structure of desire, in which the subject desires to become the object of the Other's desire.

Love is a bond between a man and a woman who are thought to be missing parts of each other and complete each other. One's life is like a puzzle and the lover is the last piece which completes his identity and the two lovers reach a sort of oneness in their relationship. However, such is not the case in Lacanian psychoanalysis because he argues that there is never one true love between the people who claim to love each other. What a person realizes as his true love is nothing but an illusion of what he wants to see based on his self-image and his ideal picture of his beloved. He writes in Seminar XX, "Love, while it is true that it has a relationship with one, never makes anyone leave himself behind. How can there be love for an other" (p. 47). Contrary to general idea of love as the bond between the two that makes them one, Lacan introduces love as a non-relation which is based on difference rather 
than wholeness and harmony. In fact, Lacan emphasizes on the impossibility of love as the union between two human subjects and always insists on otherness in this relationship.

\section{Discussion}

\subsection{Bondage to Love}

Love is an apparently complex issue in Of Human Bondage. Nevertheless, it is an inevitable necessity in Maugham's work. He depicts a perplexed relationship between those in love where women are mostly portrayed as evil characters that satisfy sexual urges of men and deceive them to reach their own objectives. On the other hand, men are shown to be less in control of their passions and always fall prey to their whimsical desires. Philip is no exception to other characters of Maugham. In his difficult life, Philip develops different relationships with other people and experiences love and hatred at different levels. In order to perform a full analysis of his subjectivity and effects of love on his life, the present study investigates Philip's relationships with other people into different levels. One significant fact about Maugham's Of Human Bondage is the nature of love which is completely a worldly affair and is mostly related to bodily needs, devoid of any spiritual or supernatural element in it. Philip asserts his wonder of the nature of love:

He did not know what it was that passed from a man to a woman, from a woman to a man, and made one of them a slave: it was convenient to call it the sexual instinct; but if it was no more than that, he did not understand why it should occasion so vehement an attraction to one person rather than another. It was irresistible: the mind could not battle with it; friendship, gratitude, interest, had no power beside it. Because he had not attracted Mildred sexually, nothing that he did had any effect upon her. The idea revolted him; it made human nature beastly; and he felt suddenly that the hearts of men were full of dark places (Bondage, p. 777).

Philip loves Mildred passionately and erroneously thinks that he can possess her as the object of his desire. Nevertheless, this relationship proves to be a sort of bondage to him and he falls prey to Mildred's desire, submitting to what she likes and suppressing his own subjective desires. Gradually, Philip loses his freedom and loses chances to develop and pursue his wish to be a doctor, and even loses a considerable amount of fortune. All his reasoning, power, and intelligence are eradicated by his passion for Mildred. Philip's story echoes Lacanian theory that love is a bondage and true love never occurs between two human beings with different perspectives and desires. His continuous submission to Mildred's whimsical and capricious desires make him an slave to his love and, increasingly, wipes out his sense of selfhood and freedom, making him a desiring addict to Mildred's love and her alternative presence. Longing for love and being loved, Philip feels disappointed and begs Mildred for affection and love. Humiliated and wounded each time he visits Mildred, he grows more isolated and loses his own true identity. Through this anti-romantic relationship, Maugham shows that submission to passion robs human liberty and leads to bondage.

Philip does not care about Mildred's love and only wants her to let him love her. This way, he makes 
himself seem like a beggar that begs love and compassion. The narrator says, "He abased himself. He poured out an incoherent story of love and penitence" (Bondage, p. 599). When Philip is with Mildred, he forgets his human dignity and only desires to be with her but she ignores him most of the times: "You never make allowances for me. It's all very well to be jolly and amiable when you're indifferent to anyone. It's very hard when you're as much in love as I am. Have mercy on me. I don't mind that you don't care for me. After all you can't help it. I only want you to let me love you" (Bondage, p. 599). In fact, Philip gradually debases himself and only desires to love Mildred, no matter what she feels about him. Philip grows fonder of Mildred and his desire to be with her grows stronger every moment: "Each day he found that he was more passionately devoted to her; and his unsatisfied love became angry and resentful" (Bondage, p. 311).

In Lacan's theory of love and desire, one is obsessed with an ideal idea of love of an Other person, which is never fully satisfied as the other person is not what one desires. The pleasure to have one's object of desire is forever postponed in the chain of human relations. Cronshaw describes this sense of desire and pleasure for Philip: "The desire for pleasure was the only motive of human action urged them blindly on, and the very vehemence of the desire seemed to rob it of all pleasure" (Bondage, $\mathrm{p}$. 480). At this point, Philip is still immature since he cannot control his love bondage. Later on, this love bondage changes into an obsession. Philip is obsessed by his passion of getting Mildred and he thinks he has to get her whatever the consequence is. At this time, Philip's attitude has not become mature because he cannot handle his desire of getting Mildred's affection.

Philip himself has no specific reason for loving Mildred and finds no merit in Mildred's behavior to attract him. But, he feels unable to control his passion. "He had read of the idealization that takes place in love, but he saw her exactly as she was. She was not amusing or clever, her mind was common; she had a vulgar shrewdness which revolted him, she had no gentleness nor softness" (Bondage, p. 684). In fact, Philip knows that Mildred has lots of shortcomings but insists on loving her and contributes to his own destruction. As he loves her more and more, she grows more indifferent to her and treats him as a butler that is in the service of her desires. Mildred knows that Philip can never overcome his strong passion and exploits that for her own benefit. By doing so, Philip becomes more entangled in his love and contributes to his own destruction. In simple words, Mildred is the source of misery for Philip and all the things he learns through the course of the novel is interpreted in this level of relationship. Philip grows with even a greater level of maturity in this relationship. As Robert Calder (1973) argues in Somerset Maugham and the Quest for Freedom, "it is usually part of a young man's apprenticeship that he becomes ensnared by a woman who is vulgar, insensitive and unintelligent. In most cases the hero finally frees himself and, although emotionally scarred, is more mature because of his experience" (p. 90).

The more Philip engages in his relationship with Mildred, the more he grows aware of Lacan's theory of love that is the source of agony and pain for the lover. Early in his relationship, he is affectionately in love with Mildred and the idea of loving someone because "He had thought of love as a rapture 
which seized one so that all the world seemed spring-like, he had looked forward to an ecstatic happiness; but this was not happiness; it was a hunger of the soul, it was painful yearning, it was a bitter anguish, he had never known before" (Bondage, p. 562). However, gradually, he learns that love is not only having passionate desire for a person that matches one's missed half and completes him. Rather, it is a bondage that makes one feel devoid of his self. Philip realizes the true nature of love in his association with Mildred: "Love was like a parasite in his heart. This love was a torment, and he resented bitterly the subjugation in which it held him; he was a prisoner" (Bondage, p. 605).

\subsection{Masochistic Desire}

Philip does not initially develop a sense of love in his first encounter with Mildred. Mildred is a thin and unattractive waitress in a teashop in London. Philip's friend Dunsford likes to make himself closer to her and understand her better, and Philip tries to help him by talking to her. But, Mildred uses vulgar language and shows no civility in her manner, which irritates and repulses Philip. That is the beginning of the relation between Philip and Mildred but there is certainly nothing visible of the usual signs of love between the two. In fact, in their early encounters, Mildred was a source of irritation for Philip and he couldn't understand why he returned to her so often. The narrator reports Philip's uncertainty: "It was convenient to call it the sexual instinct, but if it was no more than that, he did not understand why it should occasion so vehement, so irresistible an emotion, deep down in his heart was mortified pride, his passion had begun in wounded vanity" (Bondage, p. 622).

Mildred is a realistic character and, unlike Philip who lives with an imaginary image of others, has a realistic perception of the world and people and seeks only to work for her own benefits. The narrator of the novel depicts an almost all negative picture of Mildred as an unpleasant and callous woman that possesses no positive qualities of a typical woman figure. She is not an ideally beautiful and pleasant woman that is the object of the love in many classic novels and her personality is extremely distasteful, as is her appearance. "Philip did not find anything attractive in her. She was tall and thin, with narrow hips and the chest of a boy" (Bondage, p. 540). Moreover, she shows no true motherly feelings towards her own baby and seems to be indifferent about what happens to her because she cannot convince herself to raise a baby: "Philip had expected the maternal instinct to make itself felt when she had had the baby two or three weeks and had counted on this to help him persuade her to keep it; but nothing of the sort occurred. Mildred was not unkind to her baby; she did all that was necessary; it amused her sometimes, and she talked about it a good deal; but at heart she was indifferent to it" (Bondage, p. 713). A close analysis of Philip's psyche and his relationship with other people, as well as his love affairs, shows that he is a masochistic person and contributes to hurting his own self. Frederick Weiss (1973) attributes this problem in his article "Of Human Bondage" to overprotection by his mother followed by a series of rejection and humiliation episodes he experiences in different phases of life with different people, for instance, by his uncle and his peers in school. This gives rise to a feeling of self-contempt and humiliation that scars his own idealized image of himself and makes him feel inferior to others in all his social and interpersonal relations. It is a self-defeating feelings that blocks his normal 
development of identity and makes him weak in dealing with the desire to demand something that degrades him. He proves to be unable to overcome this problem and master his desires.

According to Dominick Barbara (1974) in "Masochism in Love and Sex", masochism "is also applied to self-induced psychological suffering such as shame, humiliation, and rejection, not necessarily connected with sexual intercourse" (p. 73). Thus, masochism is the best word that defines Philip's relationship with Mildred. Throughout the novel, Philip experiences different level of relations and almost always shows masochistic behavior. He suffers too much before he comes to understand life. The interesting thing is that he is not only the object of sufferings caused by external factors and people, but also searches for that and invites sufferings. That is why we call his behaviors and attitudes masochistic.

Philip's masochism may arise from his humiliation in his childhood and his being rejected by other members in the society. People with masochistic disorder like to be with those who humiliate them and this explains why Philip enjoys being with Mildred. He hates himself because of his physical deformity and loves Mildred because she makes him recognize the same contempt he has for himself. The desire to hurt himself is an integral aspect of his personality. Being with Mildred does not give him pleasure, but more pain than he feels and experiences in daily life: "He only remembered that each time he had gone into the shop, after the first two or three times, it had been with a little feeling in the heart that was pain; He stretched himself in his bed as a dog stretches himself. He wondered how he was going to endure that ceaseless aching of his soul" (Bondage, p. 562). All this might also be due to his desire to hurt himself. This is the only thing which helps us understand the reason for Philip's behavior because it shows the masochistic aspect of love and desire.

The relationship between Philip and Mildred has always been this way. Philip's desire to hurt himself becomes more evident when we see that he does not like to show that there are things about Mildred that hurt him. They always quarrel over things because they are different from each other. Mildred never feels guilty for her action which always hurts Philip. On the other hand, Philip tries to suppress his feeling. Even though his heart is hurt, he pretends that there is nothing wrong with his feeling. He hides his real feeling in front of Mildred:

By an effort he made himself affable and entertaining; he never let himself be angry, he never asked for anything, he never complained, he never scolded. When she made engagements and broke them, he met her next day with a smiling face; when she excused herself; he said it did not matter. He never let her see that she pained him. He understood that his passionate grief had wearied her, and he took care to hide every sentiment which could be in the least degree troublesome (Bondage, p. 615).

As can be seen in the above quotation, Philip intentionally engages in situations where his sense of pride, humanity and self-esteem is challenged or even belittled. When he can avoid Mildred and her bad temperament, he deliberately makes things worse to tease her, which finally led her anger and his own final humiliation: "There was a devil within him which forced him to make matters worse. He wanted to hurt her as much as she was hurting him" (Bondage, p. 573). He asks his friend Griffiths to 
come to dinner with them so that Mildred may like his talk and be friendlier with him. Then, Mildred falls in love with Griffiths and Philip can do nothing. Interestingly, instead of fighting Griffiths away as his rival in love, Philip masochistically gives money to them to go to a holiday and enjoy their time.

Such treatment then makes the masochist feel better than the other, as he can demonstrate how nice, generous, and pleasant he is in spite of the horrible behavior of the other. He is a victim of the partner, and can hate the partner for being so cruel when he is so good in return. The pain the other induces simultaneously accomplishes two things: Firstly, it allows the masochist to feel bad because his partner's treatment confirms that he really is as despicable as he himself believes deep down. Secondly, the pain brings pleasure because the masochist gets to demonstrate his own goodness. The desire to hurt oneself to make the beloved happy is seen in many parts of the novel: "The desire to wound had been too strong for him. He had wanted to revenge himself for the pain and the humiliation he had endured. It was pride: it was folly too" (Bondage, p. 147). Thus, we can see that Philip himself enjoys being humiliated to show that he is superior to others.

\section{Conclusion}

It is argued in this study that Philip is slave to his desire and his desire is whatever that Mildred desires. In simple words, Philip has no autonomous and self-regulated desire of his own because in his desire is initially driven by the strong passion to make Mildred happy and satisfied. Thus, Philip's ultimate goal in life is to have Mildred and he thinks that the way to win her heart is to eliminate all his subjective desires for that of Mildred. Based on Lacanian theory of desire, it is argued that Philip is the victim to his blind love of Mildred which is formed on the basis of a wrong perception of Mildred as the ultimate object of his desire. Philip mistakenly believes that Mildred is his ideal queen and is the source of happiness for him. Nevertheless, as he grows more dependent on her and becomes aware of his personality, Philip realizes that she is not his type and he will never experience happiness with her. Interestingly, he is unable to leave her and get back to lovely Norah who will always receive him with open arms and a kind heart. The reason is his unquenchable desire that drives him into selflessness and perdition. The title of the novel, Of Human Bondage, is in fact a reference to Philip's bond to his desire towards cold and unlovely Mildred who brings him nothing other than misery.

Philip's desire towards Mildred is somehow masochistic. Philip strongly suffers from a sense of self-contempt because of his club-foot and his need for a true love from others which is denied to him in the vicarage and the boarding school. This makes him helpless while encountering other people and makes him hurt himself when he comes across a stronger personality. Early in his relationship with Mildred, Philip understands that he does not deserve his love but he wants to continue the relationship because he wants to hurt her as well as himself. Philip hates himself for his lack of self-confidence to defend himself when downgraded by other people, at school, or art gallery or anywhere in the society. Mildred gives him the same sense of contempt that he used to experience in the past. Mildred increases his suffering and adds to his inner conflict of self-contempt and self-acceptance. That is to say, Philip's 
desire for her is motivated by the idea that if he can make himself accepted by Mildred, he can come to terms with his own contempt of himself and can prove himself to others as an acceptable person.

In simple words, Mildred becomes an obsessive idea for Philip. His hunger for Mildred and his strong desire to have her are informed by his desperate longing for inner peace and freedom from self-contempt. In order to win her, Philip invites his friend Griffiths to amuse Mildred and soften her coldness towards her. But, instead, Mildred falls in love with Griffiths and hurts Philip even more. Nevertheless, out of his masochistic desire for her, Philip unbelievingly pays for Mildred's trip to France with Griffiths to prove how one's irrational desire may cause self-destruction. Afloat with his desire for Mildred and driven by his passionate love for her, Philip intensifies his pain by engaging more in pursuing his love of Mildred.

Our analysis shows that Philip is bond to his inner conflict: he knows that Mildred causes him only humiliation and brings him no good except gradual loss of identity and self degradation. On the other hand, he cannot convince himself to leave her and pursue his own plans to be a doctor and actualize his real identity. This inner conflict is resolved only when he stops loving Mildred and forgets her. The interesting thing about Philip is that he finally abandons the love of Mildred but can never truly get rid of his desire towards her until she leaves him forever and he finds a chance to realize his personal dreams. At the final stages of their relationship, Philip fells more pity and sympathy, than passionate love, for Mildred and helps her out of humanity, not love. Nevertheless, throughout their long relation, Philip was a desiring person whose desire was defined and determined by Mildred and her whimsical demands for materialistic mastery over Philip and his life.

\section{References}

Brander, L. (1963). Somerset Maugham: A Guide. London: Oliver and Boyd Ltd.

Burt, F. (1970). William Somerset Maugham: An Adlerian Interpretation. Journal of Individual Psychology, 26(1), 64-82.

Calder, R. (1992). Introduction to Of Human Bondage, by W. Somerset Maugham. Harmondsworth: Penguin Classics.

Collins, J. (1919). W. Somerset Maugham, Playwright and Novelist. London: Bookman.

Cordell, R. A. (1961). Somerset Maugham: A Biographical and Critical Study. Bloomington: Indiana University Press.

Curtis, A. (1987). W. Somerset Maugham: The Critical Heritage. London: Taylor \& Francis Library. https://doi.org/10.4324/9780203198995

Jensen, S. A. (1957). William Somerset Maugham: Some Aspects of the Man and his Work. Oslo: Oslo University Press.

Lacan, J. (1977). Ecrits: A Selection (A. Sheridan, Trans.). New York: Norton.

Maugham, W. S. (1968). The Art of Fiction: An Introduction to Ten Novels and Their Authors. New York, N.Y:: Greenwood Press. 
Of Human Bondage. (1915). London; George H. Doran Company.

Rogal, S. (1997). A William Somerset Maugham Encyclopedia. Westport, Conn.: Greenwood Press.

Spence, R. (1951). Maugham's Of Human Bondage. The Library Chronicle, 17(2), 104-114.

The Pattern of Maugham. (1974). London: Hamish Hamilton.

The Seminar of Jacques Lacan, Book V11, The Ethics of Psychoanalysis (M. Jacques-Alain, Ed.; D. Porter, Trans.). (1992). Routledge.

The Summing Up. (1986). Middlesex: Penguin.

Weiss, F. (1973). Of Human Bondage. American Journal of Psychoanalysis, 33(1), 68-76. https://doi.org/10.1007/BF01872142 